\title{
Knowledge and attitudes towards stem cells and the significance of their medical application among healthcare sciences students of Jouf University
}

\author{
Abdulrahman Almaeen ${ }^{1}$, Farooq Ahmed Wani ${ }^{\text {Corresp., }}{ }^{2}$, Ashokkumar Thirunavukkarasu ${ }^{3}$ \\ ${ }^{1}$ Department of Pathology, College of Medicine, Jouf University, Sakaka, Aljouf, Saudi Arabia \\ 2 Department of Pathology College of Medicine, Jouf University, Sakaka, Aljouf, Saudi Arabia \\ 3 Department of Community Medicine, College of Medicine, Jouf University, Sakaka, Aljouf, Saudi Arabia \\ Corresponding Author: Farooq Ahmed Wani \\ Email address: fawani@ju.edu.sa
}

Background Adequate knowledge and positive attitude of the medical and dental students towards the stem cells and their utilization in medical science is extremely important keeping in view the ever increasing potential of stem cells in the medical field. The present study was planned to assess the knowledge and attitude of the medical and dental students towards stem cells and their applications in medical science. Methods This cross-sectional study was conducted among 217 medical and dental college students of the Jouf University. The systematic random sampling method was used to select students based on gender and year of study. After obtaining written informed consent, a self-administered questionnaire consisting of three parts was administered to the students. The first part collected the socio-demographic details; part 2 contains 15 questions regarding knowledge and part 3 contains 10 questions regarding attitude towards stem cells. Results Majority of the participants were males (54.4\%) in the age group of 21-22 years. Awareness regarding Saudi stem cell donor registry was observed in $50.7 \%$ of the students. $72.4 \%$ of the students possessed medium knowledge while $70 \%$ of the students possessed high attitude score towards stem cell research and its medical significance. A significant relationship was observed between the Saudi Stem Cell Donor Registry awareness and knowledge score with $p$-value of 0.04 . Relationship between the knowledge and attitude scores was significant with $p$-value of 0.001 and with Pearson correlation score of $r=0.334$. Conclusion Medium to high level of knowledge was noted among majority of the participants and a high attitude score was also noted towards stem cells and their relevance. A significant positive correlation was observed between the knowledge and attitude scores. It is recommended to include various interventional educational programs for the medical and dental students on the significance of stem cells in the medical field. 
1 Knowledge and attitudes towards stem cells and the significance of their medical

2 application among healthcare sciences students of Jouf University

3 Abdulrahman Almaeen ${ }^{1}$, Farooq Ahmed Wani' ${ }^{2}$, Ashokkumar Thirunavukkarasu ${ }^{3}$

Authors 
29 Abstract

30

31

32

\section{Background}

Adequate knowledge and positive attitude of the medical and dental students towards the stem cells and their utilization in medical science is extremely important keeping in view the ever increasing potential of stem cells in the medical field. The present study was planned to assess the knowledge and attitude of the medical and dental students towards stem cells and their applications in medical science.

\section{Methods}

This cross-sectional study was conducted among 217 medical and dental college students of the Jouf University. The systematic random sampling method was used to select students based on gender and year of study. After obtaining written informed consent, a self-administered questionnaire consisting of three parts was administered to the students. The first part collected the socio-demographic details; part 2 contains 15 questions regarding knowledge and part 3 contains 10 questions regarding attitude towards stem cells.

\section{Results}

Majority of the participants were males (54.4\%) in the age group of 21-22 years. Awareness regarding Saudi stem cell donor registry was observed in $50.7 \%$ of the students. $72.4 \%$ of the students possessed medium knowledge while $70 \%$ of the students possessed high attitude score towards stem cell research and its medical significance. A significant relationship was observed between the Saudi Stem Cell Donor Registry awareness and knowledge score with p-value of 0.04. Relationship between the knowledge and attitude scores was significant with $p$-value of 0.001 and with Pearson correlation score of $\mathrm{r}=0.334$.

\section{Conclusion}

Medium to high level of knowledge was noted among majority of the participants and a high attitude score was also noted towards stem cells and their relevance. A significant positive correlation was observed between the knowledge and attitude scores. It is recommended to 
56 include various interventional educational programs for the medical and dental students on the 57 significance of stem cells in the medical field.

58 Keywords: Stem cells; awareness; knowledge; attitude; correlation; medical.

59

60

61

62

63

64

65

66

67

68

69

70

71

73

74 75

72 Introduction

9

0

61

62

63

64

65

66

67

68

69

70

73 Stem cells are characterized by the intrinsic ability of perpetual self-renewal and can differentiate

74 into specific cell types. Stem cells in general are classified into embryonic and adult stem cells.

75 Embryonic stem cells are pluripotent signifying thereby their ability to differentiate into all cell

76 types of the body. On the other hand, adult stem cells possess only restricted potential of

77 differentiation and can differentiate into the cell types of their tissue of origin (National Institutes

78 of Health resource for stem cell research).

79 Stem cells not only play a crucial role in tissue and organ maintenance by replenishing the dying 80 cells but also helps to repair and regenerate the damaged tissues (Fujimaki et al. 2013). Stem

Peer] reviewing PDF | (2020:08:52220:2:0:NEW 1 Dec 2020) 
81 cell therapy is of utmost importance for treating and curing many hematological malignancies.

82 Stem cell therapy promises hope for many incurable diseases like neurodegenerative diseases,

83 diabetes, cardiac disease, etc. but it is still in the experimental phase (Ray et al. 2015).

Promising results have been found in the clinical trials when stem cells are used for treating multiple sclerosis (Muraro et al. 2017), type I diabetes, and spinal cord injury (Prentice 2012).

Embryonic stem cells can be directed to differentiate along many different cell lines and appear to be very promising to treat different types of diseases but such research is associated with legal, ethical and social implications (Pandey et al. 2016). Umbilical cord blood (UCB) stem cells obtained from the blood in the umbilical cord and placenta are being preferred because of high proliferative potential, low antigenicity, decreased incidence of graft-versus-host reaction, without ethical implications and can be transplanted even without an identical HLA match (Habib \& Gordon 2006; Ikuta 2008).

Adult stem cells may be used for autologous or allogeneic transplantation for the treatment of hematologic malignancies and degenerative disorders. The risk of graft rejection is avoided in autologous transplantation (Dimarakis et al. 2005). Promising results have been found in clinical trials involving the regeneration of cardiac muscle (Gordon et al. 2006) and liver tissue (Levičar et al. 2008).

Medical and allied medical students are expected to have reasonable knowledge regarding stem cells and possess a positive attitude regarding their application in medicine. Variable results have been found in the different studies conducted throughout the world. Lye et al showed that the nursing students possessed moderate knowledge and a positive attitude towards stem cell therapy (Lye et al. 2015). One of the studies conducted in Tabuk, Saudi Arabia revealed sub-optimal knowledge, attitude, and practice among the final class medical students and doctors regarding the use of stem cells in the management of diabetes (ALtemani et al. 2018). An educational interventional study on stem therapy done in Saudi Arabia on nursing students found poor knowledge but a positive attitude prior to the intervention. However after educational intervention, a significant increase in the level of knowledge was observed (Azzazy MH and Mohamed FH 2016; Walker et al. 2012). Throughout the World, public cord blood banks (CBBs) store more than 700,000 UCB units. There are 2 public CBBs in Saudi Arabia but no private CCBs are present (Jawdat et al. 2018). Most studies have shown inadequate knowledge 
111 and awareness among public and healthcare staff about CB banking (Perlow 2006; Suen \& Lao

112 2011; Tuteja et al. 2016).

113 The present study was planned to assess the knowledge and attitude of the students of Medical

114 College and Dental College towards stem cells and their applications in Medical science and to

115 correlate knowledge and attitude scores among them.

116 Methodology:

117 Study design and Settings:

118 This cross-sectional study was conducted among the medical and dental college students of Jouf

119 University. Jouf University is situated in the Sakaka region of Aljouf province in the Kingdom of

120 Saudi Arabia. Currently, this is the only university serving in this region. The total registered

121 student in both medical and dental colleges of the Jouf University in the year 2019-20 is 662.

122

123 Sample Size Estimation:

124 The sample size was calculated based on the Cochrane's formula of sample size estimation (n

$125=\mathrm{z}^{2} \mathrm{pq} / \mathrm{e}^{2}$ ), where $\mathrm{n}$ is the minimum required sample size, $\mathrm{z}$ is desired confidence interval (95\%),

$126 \mathrm{p}$ is the proportion, $\mathrm{q}=1-\mathrm{p}$ and $\mathrm{e}$ is the desired level of precision (5\%). We have taken $50 \%$ as

127 population proportion (p) to estimate the sample size for the present study. Applying the above

128 formula and values with the finite population of 662 , the estimated sample size was calculated as 129244.

130 Sampling method:

131 A multistage probability proportional to size (PPS) sampling method was applied to select the

132 study participants. Firstly, the required number of students from each college was selected based

133 on the total number of registered students from that college. In the next stages, the required

134 fractions of participants from each year, and gender also were selected based on PPS. By using

135 the university identification number of each student, the systematic random sampling method

136 was used to select from each gender and year.

137 Ethical consideration: 
138 The Local Committee for Bioethics (LCBE) of Jouf University had given ethical clearance to

139 conduct this study (Approval no: 09-02/41). The data was collected from the participants after

140 their willingness to participate given through written informed consent.

\section{Data collection procedure:}

142 After completion of necessary approval formalities, the data collection process was initiated. The

143 selected students were communicated through their class leader on their availability for data

144 collection. Data collection during examination time was avoided as students may not be

145 available. All the registered students of the medical and dental college of the academic year

146 2019-20 were included in the study. The research team made three attempts in one month to

147 communicate with the selected students. Those students who could not be contacted by the

148 principal and co-investigators despite three attempts in one month or those participants who were

149 not willing to participate were considered as non-respondent.

\section{Data collection instrument:}

151 After obtaining written informed consent, a paper form of self-administered questionnaire was given to study participants. This questionnaire was adapted from a previously published study by Lye et al (Lye et al. 2015). The scale used in their study has the Cronbach alpha of 0.67 for knowledge section and 0.86 for attitude section. A pilot study was done among 30 medical and dental college students of Jouf University using the above adapted questionnaire. The results from pilot study showed the Cronbach alpha of 0.71 for knowledge section and 0.81 for attitude section, which exhibited good internal consistency in the format used. Hence, we proceeded with the adapted questionnaire and it consisted of three parts as mentioned below. The first part collected the socio-demographic details such as age, gender, college type, year of education, marital status, and smoking behavior of study population. This section also inquired about participants' awareness about Saudi Stem Cells Donor Registry. In part 2, participants responded to 15 items that assessed their knowledge of stem cells and their uses in medical sciences. Selected respondents had to choose yes or no for each item. The responses yes were given as 2 marks and no was given as 1 mark. Hence the expected range of scores is 15 to 30 . The obtained knowledge scores were divided into three categories namely low (15 - 20), medium (21 - 25), and High (26 - 30). Part 3 consists of 10 items and responses were recorded on a 5-point Likert scale: Strongly agree, agree, not sure, disagree, and strongly disagree. Scores of responses were 
168 given; five for strongly agree to one for strongly disagree. Since there were 10 items in attitude 169 sections, the range of scores varied from ten to fifty. The obtained attitude scores were divided 170 into four categories namely low $(10-20)$, medium $(21-30)$, good (31 - 40), and excellent (41 $17150)$.

\section{Statistical Analysis:}

173 Statistical package for social sciences (SPSS, USA) version 21.0 were used for data entry and 174 analysis. Descriptive data of the study were presented as frequency (n) and percentage and 175 quantitative data were presented as mean and standard deviation (SD). The data were checked 176 for normal distribution through kurtosis -skewness analysis and Kolmogorov-Smirnov 177 test . The kurtosis-skewness values of the sample met the normality assumption of data (Kurtosis 178 and skewness value of knowledge score were 0.148 and 0.001 , and for attitude score were -0.350 179 and -0.064). The statistical values of Kolmogorov-Smirnov tests of knowledge and attitude 180 scores were 0.111 and 0.059 respectively. Independent t-test and one-way analysis of variance 181 (ANOVA) were applied to compare the knowledge and attitude mean scores with the different 182 socio-demographic characteristics of the study population as a hypothetical test. Chi-square test 183 was done to find the association between different socio-demographic characteristics of the study

184 185 186 187 188 population and their awareness about Saudi Stem Cell Donor Registry (SSCDR). Pearson's correlation test was applied to find the correlation between knowledge and attitude scores. A correlation coefficient value was interpreted as follows: less than 0.30 is a negligible correlation, 0.30 to 0.50 is a weakly positive correlation, 0.51 to 0.70 is a moderately positive correlation, 0.71 to 0.90 is a high positive correlation and more than 0.90 is a very high positive correlation (Freedman 2007). A p-value of less than 0.05 was considered a statistically significant association between independent and outcome variables. All the statistical tests applied in the present study were two-tailed.

\section{Results}

Majority of the participants in our study were males (54.4\%) and in the age group 21-22 years. $61.3 \%$ of the students were from the Medical College and maximum (27.2\%) were studying in $3^{\text {rd }}$ year. Only $7.4 \%$ of the students were married. $12.4 \%$ of the participants were daily smokers (Table-1). 
197157 (72.4\%) of the students possessed medium knowledge while $23 \%$ had high level of

198 knowledge regarding stem cells. Majority (70\%) of the students possessed high attitude score 199 towards stem cell research and its medical significance whereas $18.9 \%$ had excellent attitude 200 score (Table-2).

201 Relationship between the age, gender, college type, year of education, marital status and 202 smoking status with the knowledge and attitude scores was not found to be significant (Table-3).

203 Relationship between the SSCDR Awareness and knowledge score was significant with p-value 204 of 0.041 whereas it was insignificant (p-value of 0.158) when it was compared with attitude 205 score (Table-3).

206 A significant positive correlation $(\mathrm{r}=0.334, \mathrm{p}<0.001)$ was obtained between the knowledge and 207 attitude scores

208 A significant association was observed between the SSCDR and gender of the participants (p209 value of 0.020$)$ and their smoking status (p-value of 0.002) (Table-4).

\section{Discussion}

212 Stem cells and their derived products offer considerable hope and assurance in devising new medical treatments. Stem cells play a great role in the field of transplant and regenerative medicine. In stem cell transplants, stem cells are used to replace the cells that have been destroyed by diseases and chemotherapy and have extremely beneficial effects in achieving remissions and cure in diseases like leukemias, lymphomas, and multiple myeloma. In regenerative medicine, they have immense potential of promoting the repair response in diseased, dysfunctional or injured tissue (MayoClinic 2019). The knowledge and attitude of health care providers regarding stem cells is extremely important as they provide a reliable source of information to the patients which in turn improves the decision making power of patients regarding use of stem cells as a novel and innovative method of treatment (Tork et al. 2017). Health care professionals are considered as the most trustworthy, dependable and reliable source of information about stem cells and umbilical cord blood banking by the members of public (Dinç \& Şahin 2009; Perlow 2006; Rucinski et al. 2010; Venugopal et al. 2016). 
225 Majority of the participants in our study were males (54.4\%) in the age group of 21-22 years.

226 Nearly $2 / 3^{\text {rd }}$ participants were Medical College students with $27.2 \%$ studying in the $3^{\text {rd }}$ year.

227 Only $7.4 \%$ of the students in our study were married whereas $12.4 \%$ were daily smokers (Table-

228 1). Lye et al in a study on undergraduate nursing students observed majority of the students were

229 female $(93.2 \%)$ from $3^{\text {rd }}$ year (34\%); maximum with matriculation $(81.8 \%)$ as their qualification

230 and Islam (97.7\%) was the predominant religion (Lye et al. 2015). Jawdat et al in a study on

231 public awareness of cord blood banking noted female predominance (88\%), mostly college

232 graduates (57\%); and maximum participants (26\%) were in the age group 19-25 years and

233 belonged to the middle class socioeconomic status (82\%) (Jawdat et al. 2018).

234 Majority of the students possessed medium to high level of knowledge whereas poor knowledge

235 was observed only in $4.6 \%$ of the students (Table-2). Lye et al noted in their study that $92 \%$ of

236 the nursing students had moderate knowledge score (Lye et al. 2015). Venugopal et al. 2016

237 observed in their study that most of the nurses' possessed good knowledge (42.86\%) with a mean

238 knowledge score of $16.84 \pm 4.59$ (Venugopal et al. 2016). We came across one study done by

239 Altemani et al on doctors and medical students in the Tabuk city regarding the knowledge of

240 stem cell therapy in diabetes mellitus in which they found that $76.5 \%$ had fair knowledge

241 (ALtemani et al. 2018). Majority of the other studies done in Saudi Arabia have noted poor

242 knowledge of the participants regarding the stem cells. Alhadlaq et al in their study regarding

243 implications of stem cells in dentistry observed poor knowledge among the male and females

244 students (Alhadlaq et al. 2019). Jawdat et al in their study in general population observed poor

245 knowledge about Cord Blood banking with $66 \%$ of participants possessing inadequate

246 knowledge (Jawdat et al. 2018). Azzazy et al in their study on nursing students found poor

247 knowledge about stem cells therapy which however remarkably improved after educational

248 intervention (Azzazy MH and Mohamed FH 2016). AlAbdulqader et al noted overall poor

249 knowledge among the general population about the stem cells (AlAbdulqader et al. 2017). Poor

250 knowledge in these studies may be due to the fact that most of these studies were done on

251 general population. Better knowledge levels in our study may be attributed to the fact that stem

252 cells are being widely used in the Kingdom of Saudi Arabia to treat a number of diseases as well

253 as the fact that we dealt with the Medical and dental students who are future health care

254 professionals. 
255 Regarding attitude towards stem cells, we noted majority (70\%) of the students possessed high

256 attitude score and 18.9\% had excellent attitude score (Table-2). The high level of positive

257 attitude towards stem cells may be attributed to medium to high level of knowledge noted among

258 the students in our study. Lye et al observed in their study that $76.1 \%$ of the nursing students

259 possessed good attitude towards stem cell application in medical science (Lye et al. 2015). Many

260 studies done in Saudi Arabia have found positive attitude of the study participants towards the

261 stem cells and their implications in medicine. Altemani et al noted fair attitude regarding stem

262 cell transplantation in $73.1 \%$ of their participants (ALtemani et al. 2018). A moderately positive

263 attitude was also observed by Alhadlaq et al in their study (Alhadlaq et al. 2019). AlAbdulqader

264 et al however noted poor attitude of the population about the stem cells. (AlAbdulqader et al.

265 2017). Venugopal et al 2016 observed neutral attitude (78.6\%) among the nurses regarding stem

266 cells and umbilical cord blood banking with a mean attitude score of $53.75 \pm 8.26$ (Venugopal et

267 al. 2016).

268 In our study, $50.7 \%$ of the students were aware about the SSCDR stem cell donor registry

269 (Table-1). Zaini \& Al-Thagafi 2020 in their study on medical students in Taif university found

270 that $52.6 \%$ of the students had never heard about the SSCDR whereas only $5.6 \%$ of participants

271 were registered in SSCDR (Zaini \& Al-Thagafi 2020). A significant relationship was noted

272 between the SSCDR awareness and knowledge score but when compared with attitude score the

273 relationship was insignificant (Table-3). We did not find any significant relationship of the socio-

274 demographic characteristics with either the knowledge or the attitude scores (Table-3). Altemani

275 et al did not find significant statistical difference across gender, between doctors and medical

276 students regarding the knowledge, attitude, practice, and the total score (ALtemani et al. 2018).

277 Significant difference in the knowledge score between male and female participants was

278 observed by Alhadlaq et al. However regarding the attitude score, significant differences were

279 not noted between males and females (Alhadlaq et al. 2019). AlAbdulqader et al in their study

280 knowledge about stem cells observed significant role of age, level of educational and specialty of

281 the participants. However they failed to find significant contribution of the above mentioned

282 criteria as far as attitude of the participants towards stem cells was concerned (AlAbdulqader et

283 al. 2017). 
284 A significant positive correlation with $\mathrm{r}=0.334, \mathrm{p}<0.001$ was observed between the knowledge 285 and attitude scores in our study Similarly, a significant positive linear correlation was noted by 286 Alhadlaq et al between knowledge and attitude for males $(r=0.323, p=0.00)$ and females

$287(\mathrm{r}=0.392, \mathrm{p}=0.00)$. Venugopal et al. 2016 also noted a significant positive correlation $(\mathrm{r}=0.532$;

$288 \mathrm{p}<0.01)$ ) between the knowledge score and attitude score in their study on nurses regarding stem 289 cells and umbilical cord blood banking (Venugopal et al. 2016). However, Lye et al noted poor 290 correlation between the knowledge and attitude score among the study participants $(\mathrm{r}=0.08)$.

291 They also observed a $\mathrm{p}$ value $>0.05$ thereby indicating insignificant correlation between the 292 years of education and the knowledge score (Lye et al. 2015). AlAbdulqader et al in their study 293 observed weak correlation between knowledge and attitude (AlAbdulqader et al. 2017).

294 A significant association was observed between the SSCDR awareness and gender of the 295 participants (p-value of 0.020) and their smoking status (p-value of 0.002) (Table-4). To the best of our knowledge, there was no published study in local settings available that attempted to find the association between socio-demographic characteristics and awareness about SSCDR. We recommend health educational programs to increase the awareness regarding the SSCDR and its activities, which in turn will increase the knowledge and improve the attitude of the medical students towards stem cells usage.

\section{Conclusion}

302

303

304

305

306

307

308

309

310

311

312

Majority of the students possessed medium to high knowledge whereas $70 \%$ of the students possessed high attitude score towards stem cell research and its medical significance. A significant relationship was observed between Stem cell Donor Registry Awareness and the knowledge score. Significantly positive correlation between the knowledge and attitude scores was also noted. However relationship of the various demographic characteristics with the knowledge and attitude scores was not statistically significant.

It is proposed to include various interventional educational programs on the importance of stem cells in the medical field taking into account the religious, ethical, moral, cultural, and social factors. This becomes imperative in view of the importance of stem cells in the present medical scenario as well as the fact that the medical and dental students are the future health care providers. This will help the students to gain high to excellent levels of knowledge thereby 
313 increasing the positive attitude levels in the students which will be extremely beneficial in imparting proper information regarding the stem cells to the patients and general population.

\section{Strength of the study}

317

318

319

320

321

322

323

324

325

326

327

328

329

330

331

332

333

334

335

336

337

338

339

340

341

342

343

344

345

346

This research will identify the knowledge and attitude of Health Science students towards Stem cells and their applications in Medical Science. Increasing their knowledge and positive attitude will influence the local community as many times, they may be the first level contact of any health needs of people. This research may give an opportunity to implement the health education program of the Saudi center for organ transplantation in Health Science Colleges.

\section{Limitations of the study}

Firstly, the study is a cross-sectional study which identifies the association between variables, and not the causation and its direction. Secondly, the study has self-reported data only and has limitations such as subjectivity, exaggerated reports and recall bias. Finally, this research was conducted across colleges within Jouf University. This research could have been enhanced further by including health colleges from other universities in the KSA.

(1)

\section{References :}

AlAbdulqader AA, AIMulhim AM, AlMulhim FF, and Almubarak HHA. 2017. Knowledge and Attitude of Blood, Organ and Stem Cells Donation Among AlAhssa Population. International Journal of Academic Scientific Research 5:40-53.

Alhadlaq A, Al-Maflehi N, Alzahrani S, and AlAssiri A. 2019. Assessment of knowledge and attitude toward stem cells and their implications in dentistry among recent graduates of dental schools in Saudi Arabia. The Saudi Dental Journal 31:66-75. https://doi.org/10.1016/i.sdentj.2018.10.006

ALtemani MF, ELBeltagy M, ALmashori MM, ALaradi BI, majed ALtoairqi L, Swead FA, Mirghani HO, and Ibrahim Y. 2018. Knowledge, Attitude and Practice of Doctors and Medical Students towards Stem Cell Use in The Management of Diabetes Mellitus. The Egyptian Journal of Hospital Medicine 71:3308-3313.

Azzazy MH and Mohamed FH. 2016. Effect of educational intervention on knowledge and attitude of nursing students regarding Stem Cells Therapy. IOSR Journal of Nursing and Health Science 5:7580.

Dimarakis I, Habib NA, and Gordon MY. 2005. Adult bone marrow-derived stem cells and the injured heart: just the beginning? : Elsevier Science BV. 
347

Dinç H, and Şahin N. 2009. Pregnant women's knowledge and attitudes about stem cells and cord blood banking. International Nursing Review 56:250-256.

Freedman D, Pisani, R., \& Purves, R. . 2007. Statistics (international student edition). In: Pisani RP, ed. 4th Edn. ed. New York.: WW Norton \&amp; Company, .

Fujimaki S, Machida M, Hidaka R, Asashima M, Takemasa T, and Kuwabara T. 2013. Intrinsic ability of adult stem cell in skeletal muscle: an effective and replenishable resource to the establishment of pluripotent stem cells. Stem cells international 2013.

Gordon MY, Levičar N, Pai M, Bachellier P, Dimarakis I, Al-Allaf F, M'Hamdi H, Thalji T, Welsh JP, and Marley SB. 2006. Characterization and clinical application of human CD34+ stem/progenitor cell populations mobilized into the blood by granulocyte colony-stimulating factor. Stem cells 24:1822-1830.

Habib NA, and Gordon M. 2006. Clinical applications of stem cell therapy-the pros and cons of stem cell sources.

Ikuta LM. 2008. Human Umbilical Cord Blood Transplantation: What Nurses Need to Know. AACN advanced critical care 19:264-267. 10.4037/15597768-2008-3004

Jawdat D, AlTwijri S, AlSemari H, Saade M, and Alaskar A. 2018. Public Awareness on Cord Blood Banking in Saudi Arabia. Stem cells international 2018:8037965. 10.1155/2018/8037965

Levičar N, Pai M, Habib NA, Tait P, Jiao LR, Marley SB, Davis J, Dazzi F, Smadja C, Jensen SL, Nicholls JP, Apperley JF, and Gordon MY. 2008. Long-term clinical results of autologous infusion of mobilized adult bone marrow derived CD34+ cells in patients with chronic liver disease. Cell Proliferation 41:115-125. 10.1111/j.1365-2184.2008.00491.x

Lye JL, Soon LK, Wan Ahmad WAN, and Tan SC. 2015. Knowledge and Attitude about Stem Cells and Their Application in Medicine among Nursing Students in Universiti Sains Malaysia, Malaysia. The Malaysian journal of medical sciences : MJMS 22:23-31.

MayoClinic. 2019. Stem cells: Frequently asked questions about stem cell research. Available at https://www.mayoclinic.org/tests-procedures/bone-marrow-transplant/in-depth/stem-cells/art20048117 (accessed October 26, 2020.

Muraro PA, Pasquini M, Atkins HL, Bowen JD, Farge D, Fassas A, Freedman MS, Georges GE, Gualandi F, Hamerschlak N, Havrdova E, Kimiskidis VK, Kozak T, Mancardi GL, Massacesi L, Moraes DA, Nash RA, Pavletic S, Ouyang J, Rovira M, Saiz A, Simoes B, Trnený M, Zhu L, Badoglio M, Zhong X, Sormani MP, Saccardi R, and Multiple Sclerosis-Autologous Hematopoietic Stem Cell Transplantation Long-term Outcomes Study G. 2017. Long-term Outcomes After Autologous Hematopoietic Stem Cell Transplantation for Multiple Sclerosis. JAMA neurology 74:459-469. 10.1001/jamaneurol.2016.5867

National Institutes of Health resource for stem cell research. The stem cell information Stem Cell Basics page. Available at https://stemcells.nih.gov/info/basics.htm (accessed September 13, 2019.

Pandey D, Kaur S, and Kamath A. 2016. Banking Umbilical Cord Blood (UCB) Stem Cells: Awareness, Attitude and Expectations of Potential Donors from One of the Largest Potential Repository (India). PLoS One 11:e0155782. 10.1371/journal.pone.0155782

Perlow JH. 2006. Patients' knowledge of umbilical cord blood banking. JOURNAL OF REPRODUCTIVE MEDICINE-CHICAGO- 51:642.

Prentice D. 2012. Remembering pioneers in patient treatments. J Tissue Sci Eng 3:e119.

Ray P, De A, Yaghoubi S, and Khanna A. 2015. Application of Adult Stem Cells in Medicine. Stem Cells Int 2015:258313. 10.1155/2015/258313

Rucinski D, Jones R, Reyes B, Tidwell L, Phillips R, and Delves D. 2010. Exploring opinions and beliefs about cord blood donation among Hispanic and non-Hispanic black women. Transfusion 50:1057-1063.

Peer) reviewing PDF | (2020:08:52220:2:0:NEW 1 Dec 2020) 
400

401

402

403

404

405

406

407

408

409

410

Suen SS, and Lao TT. 2011. Maternal understanding of commercial cord blood storage for their offspring - a survey among pregnant women in Hong Kong. Acta Obstetricia et Gynecologica Scandinavica 90. 10.1111/j.1600-0412.2011.01201.x

Tork H, Alraffaa S, Almutairi K, Alshammari N, Alharbi A, and Alonzi A. 2017. Stem cells: knowledge and attitude among health care providers in Qassim region, KSA. International Journal of Advanced Nursing Studies 7:1. 10.14419/ijans.v7i1.8524

Tuteja M, Agarwal M, and Phadke SR. 2016. Knowledge of cord blood banking in general population and doctors: a questionnaire based survey. The Indian Journal of Pediatrics 83:238-241.

Venugopal A, Joshi P, Deka D, and Seth T. 2016. Knowledge and attitude of nurses regarding stem cells and umbilical cord blood banking in a selected tertiary care facility. Asian Journal of Nursing Education and Research 6:240-244.

Walker T, Steckler D, Spellman S, Haven D, Welte K, and Boo M. 2012. Awareness and acceptance of public cord blood banking among practicing obstetricians in the United States. Transfusion 52:787-793.

Zaini R, and Al-Thagafi A. 2020. Medical Students' knowledge, attitude towards hematopoietic stem cell transplantation and donation behaviour at Taif university. Health 5:1-4. 


\section{Table 1 (on next page)}

Socio-demographic characteristics of the students

Socio-demographic characteristics of the students $(n=217)$ 
1 Table 1: Socio-demographic characteristics of the students $(n=217)$

2

\begin{tabular}{|l|l|l|}
\hline Variable & Frequency & Percentage \\
\hline Age (mean \pm SD) & $21.64 \pm 1.65$ & \\
Less than 21 years & 62 & 28.6 \\
$21-22$ years & 86 & 39.6 \\
Above 22 years & 69 & 31.8 \\
\hline Gender & 118 & \\
Male & 99 & 54.4 \\
Female & & 45.6 \\
\hline College type & 133 & \\
Medical & 84 & 61.3 \\
Dental & & 38.7 \\
\hline Year of education & 55 & \\
$1^{\text {st }}$ & 48 & 25.3 \\
$2^{\text {nd }}$ & 59 & 22.1 \\
$3^{\text {rd }}$ & 28 & 27.2 \\
$4^{\text {th }}$ & 27 & 12.9 \\
$5^{\text {th }}$ & & 12.4 \\
\hline Marital status & 201 & \\
Single & 16 & 92.6 \\
Married & & 7.4 \\
\hline Smoking status & 27 & 12.4 \\
Daily & 28 & 12.9 \\
Rarely & 162 & 74.7 \\
Never & 110 & \\
\hline Awareness about Saudi Stem & 50.7 \\
Cells Donor Registry & 107 & 49.3 \\
Yes & & \\
No & & \\
\hline
\end{tabular}




\section{Table 2 (on next page)}

Knowledge, and attitude of the students

Knowledge, and attitude of the students towards stem cell research and its medical significance $(n=217)$ 
1 Table 2: Knowledge, and attitude of the students towards stem cell research and its medical

2 significance $(\mathrm{n}=217)$

3

\begin{tabular}{|l|l|l|}
\hline Category & Frequency & Percent \\
\hline Knowledge & & \\
High & 50 & 23.0 \\
Medium & 157 & 72.4 \\
Low & 10 & 4.6 \\
Overall mean \pm SD & $24.04 \pm 2.13$ & \\
\hline Attitude & & \\
Excellent & 41 & 18.9 \\
High & 152 & 70.0 \\
Medium & 23 & 10.6 \\
Low & 0 & 0 \\
Overall mean $\underline{\underline{S D}}$ & $36.63 \underline{\underline{S}}+.67$ & \\
\hline
\end{tabular}




\section{Table 3(on next page)}

Comparison of the mean of study participants for socio-demographic characteristics

Comparison of the mean ( + SD) of study participants for socio-demographic characteristics 
1 Table 3: Comparison of the mean $( \pm \mathrm{SD})$ of study participants for socio-demographic 2 characteristics

3

4

\begin{tabular}{|c|c|c|c|c|}
\hline & Knowledge & & Attitude & \\
\hline Variables & Mean \pm SD & p value & Mean \pm SD & p value \\
\hline $\begin{array}{l}\text { Age category } * \\
\text { Less than } 21 \text { years } \\
21-22 \text { years } \\
\text { Above } 22 \text { years }\end{array}$ & $\begin{array}{l}23.71+2.29 \\
24.35+2.05 \\
23.94+2.04\end{array}$ & 0.178 & $\begin{array}{l}37.00 \pm 4.99 \\
37.22 \pm 4.66 \\
35.57 \pm 4.24\end{array}$ & 0.680 \\
\hline $\begin{array}{l}\text { Gender** } \\
\text { Male } \\
\text { Female }\end{array}$ & $\begin{array}{l}23.80 \pm 2.06 \\
24.32 \pm 2.18\end{array}$ & 0.070 & $\begin{array}{l}36.25 \pm 4.41 \\
37.08 \pm 4.94\end{array}$ & 0.195 \\
\hline $\begin{array}{l}\text { College type** } \\
\text { Medical } \\
\text { Dental }\end{array}$ & $\begin{array}{l}24.02 \pm 1.95 \\
24.07 \pm 2.39\end{array}$ & 0.850 & $\begin{array}{l}36.64 \pm 4.44 \\
36.62 \pm 5.04\end{array}$ & 0.974 \\
\hline $\begin{array}{l}\text { Year of education* } \\
1^{\text {st }} \\
2^{\text {nd }} \\
3^{\text {rd }} \\
4^{\text {th }} \\
5^{\text {th }}\end{array}$ & $\begin{array}{l}23.87 \pm 2.29 \\
24.25 \pm 2.16 \\
24.14 \pm 2.05 \\
23.39 \pm 2.20 \\
24.44 \pm 1.72\end{array}$ & 0.344 & $\begin{array}{l}36.35 \pm 4.83 \\
37.96 \pm 4.33 \\
36.58 \pm 4.90 \\
35.18 \pm 4.83 \\
36.48 \pm 3.91\end{array}$ & 0.507 \\
\hline $\begin{array}{l}\text { Marital status** } \\
\text { Single } \\
\text { Married }\end{array}$ & $\begin{array}{l}24.01 \pm 2.15 \\
24.38 \pm 1.78\end{array}$ & 0.429 & $\begin{array}{l}36.49 \pm 4.74 \\
38.38 \pm 3.36\end{array}$ & 0.121 \\
\hline $\begin{array}{l}\text { Smoking status* } \\
\text { Daily } \\
\text { Rarely } \\
\text { Never }\end{array}$ & $\begin{array}{l}23.44 \pm 1.76 \\
24.07 \pm 2.09 \\
24.13 \pm 2.13\end{array}$ & 0.300 & $\begin{array}{l}36.11 \pm 3.86 \\
36.82 \pm 4.64 \\
36.69 \pm 4.84\end{array}$ & 0.200 \\
\hline $\begin{array}{l}\text { Stem cell Donor Registry } \\
\text { Awareness** } \\
\text { Yes } \\
\text { No }\end{array}$ & $\begin{array}{l}24.44 \pm 2.06 \\
23.74+2.16\end{array}$ & $0.041 * * *$ & $\begin{array}{l}37.07 \pm 4.94 \\
36.18 \pm 4.35\end{array}$ & 0.158 \\
\hline
\end{tabular}

5

$6 *$ One-way Analysis of Variance (ANOVA), ** Independent t-test ***Statistically significant at 7 the level of 0.05 (two-tailed) 


\section{Table 4(on next page)}

Association between socio-demographic characteristics of the students and awareness about Saudi Stem Cells Donor Registry

Association between socio-demographic characteristics of the students and awareness about Saudi Stem Cells Donor Registry $(n=217)$ 
1 Table 4: Association between socio-demographic characteristics of the students and awareness

2 about Saudi Stem Cells Donor Registry $(\mathrm{n}=217)$

3

\begin{tabular}{|c|c|c|c|c|}
\hline \multirow[b]{2}{*}{ Variable } & \multirow[b]{2}{*}{ Total } & \multicolumn{3}{|c|}{ Awareness about Saudi Stem Cells Donor Registry } \\
\hline & & Yes & No & p value \\
\hline $\begin{array}{l}\text { Less than } 21 \text { years } \\
21-22 \text { years } \\
\text { Above } 22 \text { years }\end{array}$ & $\begin{array}{l}62 \\
86 \\
69\end{array}$ & $\begin{array}{l}30(48.4) \\
46(53.50 \\
34(49.3)\end{array}$ & $\begin{array}{l}32(51.6) \\
40(46.5) \\
35(50.7)\end{array}$ & 0.796 \\
\hline $\begin{array}{l}\text { Gender } \\
\text { Male } \\
\text { Female }\end{array}$ & $\begin{array}{l}118 \\
99 \\
\end{array}$ & $\begin{array}{l}48(40.7) \\
62(62.6) \\
\end{array}$ & $\begin{array}{l}70(59.3) \\
37(37.4)\end{array}$ & $0.020 *$ \\
\hline $\begin{array}{l}\text { College type } \\
\text { Medical } \\
\text { Dental }\end{array}$ & $\begin{array}{l}133 \\
84\end{array}$ & $\begin{array}{l}70(52.6) \\
40(47.6)\end{array}$ & $\begin{array}{l}63(47.4) \\
44(52.4)\end{array}$ & 0.489 \\
\hline $\begin{array}{l}\text { Year of education } \\
1^{\text {st }} \\
2^{\text {nd }} \\
3^{\text {rd }} \\
4^{\text {th }} \\
5^{\text {th }} \\
\end{array}$ & $\begin{array}{l}55 \\
48 \\
59 \\
28 \\
27 \\
\end{array}$ & $\begin{array}{l}28(50.9) \\
20(41.7) \\
29(49.2) \\
13(46.4) \\
20(74.1) \\
\end{array}$ & $\begin{array}{l}27(49.1) \\
28(58.3) \\
30(50.8) \\
15(53.6) \\
7(25.9)\end{array}$ & 0.102 \\
\hline $\begin{array}{l}\text { Marital status } \\
\text { Single } \\
\text { Married }\end{array}$ & $\begin{array}{l}201 \\
16 \\
\end{array}$ & $\begin{array}{l}105(52.20) \\
5(31.3)\end{array}$ & $\begin{array}{l}96(47.8) \\
11(68.8) \\
\end{array}$ & 0.124 \\
\hline $\begin{array}{l}\text { Smoking status } \\
\text { Daily } \\
\text { Rarely } \\
\text { Never }\end{array}$ & $\begin{array}{l}27 \\
28 \\
162\end{array}$ & $\begin{array}{l}7(25.9) \\
10(35.7) \\
93(57.4)\end{array}$ & $\begin{array}{l}20(74.1) \\
18(64.3) \\
69(42.6)\end{array}$ & $0.002 *$ \\
\hline
\end{tabular}

4

$5 *$ Statistically significant at the level of 0.05 (Chi-square test)

6 